\title{
Bactericidal activity of hexylresorcinol lozenges against oropharyngeal organisms associated with acute sore throat
}

\author{
Derek Matthews $^{1^{*}}$ (D), Oluwajoba Adegoke ${ }^{2}$ and Adrian Shephard ${ }^{1}$
}

\begin{abstract}
Objective: For the majority of people with acute sore throat, over-the-counter treatments represent the primary option for symptomatic relief. This study evaluated the in vitro bactericidal activity of lozenges containing the antiseptic hexylresorcinol against five bacteria associated with acute sore throat: Staphylococcus aureus, Streptococcus pyogenes, Moraxella catarrhalis, Haemophilus influenzae and Fusobacterium necrophorum.

Results: Hexylresorcinol $2.4 \mathrm{mg}$ lozenges were dissolved into $5 \mathrm{~mL}$ of artificial saliva medium. Inoculum cultures were prepared in triplicate for each test organism to give an approximate population of $10^{8}$ colony-forming units (cfu)/ $\mathrm{mL}$. Bactericidal activity was measured by log reduction in cfu. Greater than $3 \log _{10}$ reductions in cfu were observed at 1 min after dissolved hexylresorcinol lozenges were added to $S$. aureus $\left(\log _{10}\right.$ reduction $\mathrm{cfu} / \mathrm{mL} \pm$ standard deviation, $3.3 \pm 0.2)$, M. catarrhalis (4.7 \pm 0.4$)$, H. influenzae (5.8 \pm 0.4$)$ and F. necrophorum ( $4.5 \pm 0.2)$ and by 5 min for S. pyogenes $(4.3 \pm 0.4)$. Hexylresorcinol lozenges achieved a $>99.9 \%$ reduction in cfu against all tested organisms within 5 min, which is consistent with the duration for a lozenge to dissolve in the mouth. In conclusion, in vitro data indicate that hexylresorcinol lozenges offer rapid bactericidal activity against organisms implicated in acute sore throat.
\end{abstract}

Keywords: Antibacterial agents, Antiseptic, Bacterial infection, Bactericidal, Pharyngitis, Sore throat

\section{Introduction}

Acute sore throat is a common symptom of an upper respiratory tract infection (URTI), associated with inflammation of the pharynx, tonsils or nasopharynx [1]. The most frequent cause of acute sore throat is a viral infection, responsible for up to $80 \%$ of cases in adults [2]. Bacterial infections are estimated to cause $5-15 \%$ of acute sore throat cases in adults [3-5]. Streptococcus pyogenes (also known as group A $\beta$-hemolytic Streptococcus or GABHS) is the most common bacterial cause of acute sore throat $[3,5]$, although other bacterial species have been implicated, including Staphylococcus aureus [6],

*Correspondence: derek.matthews@rb.com

${ }^{1}$ Reckitt Benckiser Healthcare International Ltd, 103-105 Bath Road,

Slough, Berkshire SL1 3UH, UK

Full list of author information is available at the end of the article
Moraxella catarrhalis [7], Haemophilus influenzae [8] and Fusobacterium necrophorum [9].

Antibiotics continue to be overprescribed for acute sore throat and are often unnecessary and ineffective in this setting [10], contributing to the growing problem of antibiotic resistance [11]. Even when the cause of sore throat is bacterial, in most cases it will be self-limiting and improve without the need for antibiotics [3]. For most individuals, over-the-counter treatments, such as lozenges, represent the primary option for relief from the symptoms of acute sore throat [12]. Lozenges containing the antiseptic hexylresorcinol significantly reduced the symptoms of acute sore throat over a 2-h study period in a placebo-controlled trial [13]. Furthermore, a concentration-dependent numbing effect with hexylresorcinol lozenges has been reported in healthy volunteers [14]. These effects are likely in part due to its local anesthetic

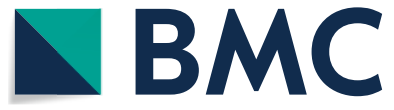

(c) The Author(s) 2020. This article is licensed under a Creative Commons Attribution 4.0 International License, which permits use, sharing, adaptation, distribution and reproduction in any medium or format, as long as you give appropriate credit to the original author(s) and the source, provide a link to the Creative Commons licence, and indicate if changes were made. The images or other third party material in this article are included in the article's Creative Commons licence, unless indicated otherwise in a credit line to the material. If material is not included in the article's Creative Commons licence and your intended use is not permitted by statutory regulation or exceeds the permitted use, you will need to obtain permission directly from the copyright holder. To view a copy of this licence, visit http://creativeco mmons.org/licenses/by/4.0/. The Creative Commons Public Domain Dedication waiver (http://creativecommons.org/publicdomain/ zero/1.0/) applies to the data made available in this article, unless otherwise stated in a credit line to the data. 
activity, achieved through blocking voltage-gated neuronal sodium channels [15]. Hexylresorcinol has also demonstrated antiviral effects against species associated with URTIs [16] or known to cause acute sore throat [17].

In vitro studies have found that hexylresorcinol has antibacterial activity against a range of species when in solution and when embedded in biopolymer composite films $[18,19]$. The antibacterial effects of hexylresorcinol in vivo may be mediated through several mechanisms including reducing bacterial adherence to the pharynx, inhibiting bacterial biofilm formation, disrupting bacterial cell chain formation, and modifying cell surface hydrophobicity [20]. However, no published studies have addressed whether hexylresorcinol lozenges have antibacterial activity against organisms implicated in acute sore throat.

This study determined the in vitro bactericidal activity of hexylresorcinol lozenges against a range of medically relevant oropharyngeal organisms associated with acute sore throat.

\section{Main text \\ Methods \\ Test samples}

Hexylresorcinol $2.4 \mathrm{mg}$ lozenges (Strepsils Extra Honey and Lemon lozenges; Reckitt Benckiser, Slough, UK) were dissolved at $44 \pm 1{ }^{\circ} \mathrm{C}$ into $5 \mathrm{~mL}$ of artificial saliva medium as described previously [21].

\section{Test organisms}

S. aureus (NCTC7445, Public Health England, Salisbury, UK), S. pyogenes (NCTC12696, Public Health England), $M$. catarrhalis (NCTC3622, Public Health England), $H$. influenzae (NCTC4842, Public Health England) and $F$. necrophorum (NCTC12238, Public Health England) were cultured as described previously [21].

\section{Bactericidal assay}

The bactericidal assay was performed using a method similar to that described previously [21]. Briefly, inoculum suspensions prepared in triplicate for each test organism, at approximately $10^{8}$ colony-forming units $(\mathrm{cfu}) / \mathrm{mL}$ in saline, were mixed with hexylresorcinol test sample $(4.9 \mathrm{~mL})$. Bactericidal activity was assayed after 1-, 5-, 10- and 30-min exposure times by combining sample/inocula mixture $(1 \mathrm{~mL})$ with neutralizing diluent $(9 \mathrm{~mL})$. Serially-diluted solutions were incubated on suitable agar medium for at least 3 days. Bactericidal activity was also assayed at the 30 -min time point for inoculum cultures $(0.1 \mathrm{~mL})$ for each test organism mixed with a positive control sample of artificial saliva medium $(4.9 \mathrm{~mL})$. Mean $\log$ reduction (in $\mathrm{cfu} / \mathrm{mL}$ ) for test samples was calculated for each organism and time point (average of three triplicates) relative to test controls.

\section{Results}

Test control counts demonstrated that the test method and media did not affect the survival of the organisms. Following test sample inoculation, evidence of bactericidal activity was recorded at the 1-min time point for all organisms (Table 1, Fig. 1). For S. aureus, M. catarrhalis, $H$. influenzae and $F$. necrophorum, the decrease at 1 min exceeded $3 \log _{10}$ (99.9\% reduction) (Table 1$)$. For S. pyogenes, a $2.9 \log _{10}$ reduction was seen at $1 \mathrm{~min}$ and a greater than $3 \log _{10}$ reduction was recorded by $5 \mathrm{~min}$ (Table 1). For all test organisms, the lower limit of detection in the bactericidal activity assay was reached at the 30-min time point (Table 1).

\section{Discussion}

Hexylresorcinol lozenges demonstrated rapid antibacterial activity against a broad range of organisms implicated in acute sore throat, including Gram-positive species ( $S$. aureus and S. pyogenes) and Gram-negative species ( $M$.

Table 1 Bactericidal activity of hexylresorcinol lozenges

\begin{tabular}{|c|c|c|c|c|c|}
\hline \multirow[t]{3}{*}{ Challenge organism } & \multirow{3}{*}{$\begin{array}{l}\text { Test control count }{ }^{*}\left(\log _{10} \mathrm{cfu} /\right. \\
\mathrm{mL} \pm \mathrm{SD})\end{array}$} & \multicolumn{4}{|c|}{ Contact time (min) } \\
\hline & & 1 & 5 & 10 & 30 \\
\hline & & \multicolumn{4}{|c|}{ Average ${ }^{a} \log$ reduction $\left(\log _{10} c f u / m L \pm S D\right)$} \\
\hline Staphylococcus aureus & $6.7 \pm 0.1$ & $3.3 \pm 0.2$ & $5.7 \pm 0.2$ & $5.7 \pm 0.2$ & $5.7 \pm 0.2$ \\
\hline Streptococcus pyogenes & $6.6 \pm 0.1$ & $2.9 \pm 0.2$ & $4.3 \pm 0.4$ & $5.6 \pm 0.1$ & $5.6 \pm 0.1$ \\
\hline Moraxella catarrhalis & $7.2 \pm 0.1$ & $4.7 \pm 0.4$ & $6.2 \pm 0.1$ & $6.2 \pm 0.1$ & $6.2 \pm 0.1$ \\
\hline Haemophilus influenzae & $6.8 \pm 0.4$ & $5.8 \pm 0.4$ & $5.8 \pm 0.4$ & $5.8 \pm 0.4$ & $5.8 \pm 0.4$ \\
\hline Fusobacterium necrophorum & $5.5 \pm 0.2$ & $4.5 \pm 0.2$ & $4.5 \pm 0.2$ & $4.5 \pm 0.2$ & $4.5 \pm 0.2$ \\
\hline
\end{tabular}

Bactericidal activity, defined as a decrease in bacterial count $\left(\log _{10} \mathrm{cfu} / \mathrm{mL}\right)$

cfu colony-forming units, SD standard deviation

${ }^{*}$ Average of the three test replicates 


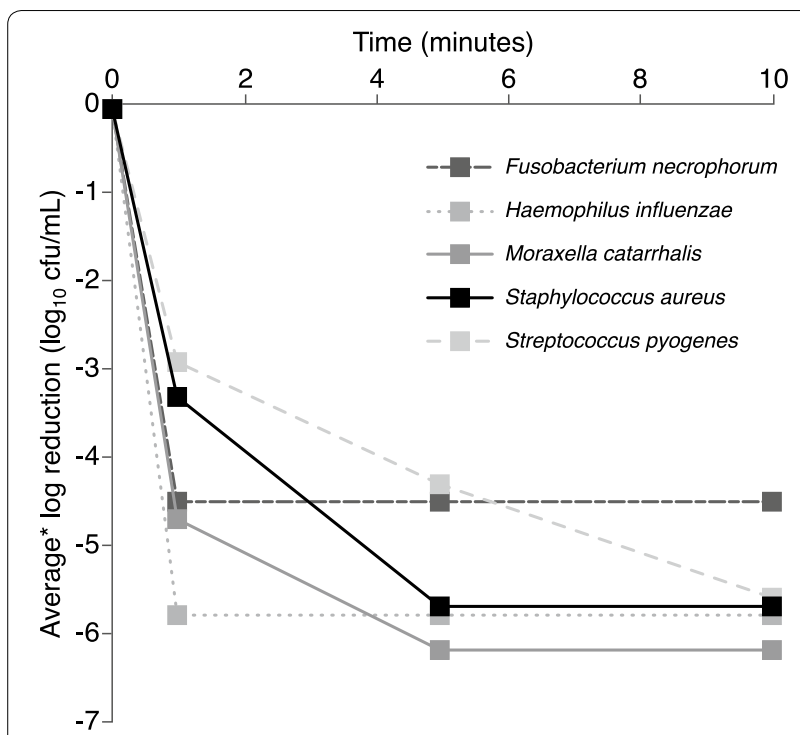

Fig. 1 Bactericidal activity of hexylresorcinol lozenges. Bactericidal activity, defined as a decrease in bacterial count $\left(\log _{10} \mathrm{cfu} / \mathrm{mL}\right)$, was measured against five common oropharyngeal organisms over a 30-min period. Only activity measurements up to $10 \mathrm{~min}$ are shown. *Average of the three test replicates. cfu colony-forming units

catarrhalis, $H$. influenzae and $F$. necrophorum). Across all test organisms, bactericidal activity was seen from the 1-min time point. For S. aureus, $M$. catarrhalis, $H$. influenzae and $F$. necrophorum, the decrease at $1 \mathrm{~min}$ exceeded $3 \log _{10}$ (99.9\% reduction). For S. pyogenes, the most common cause of bacterial acute sore throat [3], the decrease was $2.9 \log _{10}$ at $1 \mathrm{~min}$ and greater than $3 \log _{10}$ reductions were recorded by $5 \mathrm{~min}$. To the best of our knowledge, these are the first published data indicating that hexylresorcinol-containing lozenges have bactericidal activity in vitro.

The study was designed to simulate the clinical setting as far as possible, including the time taken for a lozenge to dissolve in the mouth (mean \pm standard deviation: $6.77 \pm 2.01 \mathrm{~min}$ ) [22]. Furthermore, the method was designed to replicate the expected concentration of hexylresorcinol that would be achieved when a lozenge is dissolved in the mouth, assuming a volume of $5 \mathrm{~mL}$ of saliva.

The findings in this study are consistent with previously reported antibacterial effects of hexylresorcinol in solution against a range of organisms, including Streptococcus spp. and S. aureus [18]. In addition, these data are in line with studies of other over-the-counter acute sore throat treatments. In a similar in vitro study, Matthews et al. (2018) reported that lozenges containing $0.6 \mathrm{mg}$ amylmetacresol and $1.2 \mathrm{mg}$ 2,4-dichlorobenzyl alcohol had broad antibacterial activity against a similar range of oropharyngeal organisms associated with acute sore throat. Specifically, reductions in bacterial counts exceeded $99.9 \%$ by $1 \mathrm{~min}$ for S. pyogenes, $H$. influenzae, $F$. necrophorum and A. haemolyticum, by $5 \mathrm{~min}$ for M. catarrhalis and S. dysgalactiae and by $10 \mathrm{~min}$ for $S$. aureus [21]. The antibacterial effects of hexylresorcinol lozenges reported here add to existing knowledge of their activity, which include numbing effects $[13,14]$ and antiviral activity $[16,17]$, resulting in relief of sore throat symptoms [13].

In conclusion, hexylresorcinol lozenges demonstrated bactericidal activity against medically relevant oropharyngeal organisms associated with acute sore throat from $1 \mathrm{~min}$ and achieved a $>99.9 \%$ reduction in $\mathrm{cfu} / \mathrm{mL}$ for all test organisms within $5 \mathrm{~min}$, which is in line with the duration for a lozenge to dissolve in the mouth. Thus, hexylresorcinol lozenges represent an effective over-thecounter treatment option for acute sore throat, offering rapid antibacterial, antiviral and local anesthetic effects, and may help to avoid unnecessary antibiotic prescribing, which is associated with the development of antibiotic resistance.

\section{Limitations}

- In vitro models cannot precisely replicate how lozenges will act in a patient's throat. Therefore, additional studies may be needed to confirm the antibacterial activity of hexylresorcinol lozenges in a clinical setting.

- The lower limit of detection of the bactericidal activity assay in this study was rapidly reached following addition of hexylresorcinol: by 1-min exposure for $H$. influenzae and $F$. necrophorum, 5-min exposure for $S$. aureus and $M$. catarrhalis and 10-min exposure for $S$. pyogenes. The use of more sensitive analytical methods may have allowed for a greater limit of detection.

\section{Abbreviations}

cfu: Colony-forming units; GABHS: Group A $\beta$-hemolytic Streptococcus; URTI: Upper respiratory tract infection.

\section{Acknowledgements}

Medical writing assistance was provided by Elements Communications Ltd, Westerham, UK, and was funded by Reckitt Benckiser Healthcare Ltd, UK.

\section{Authors' contributions}

DM, OA and AS participated in this study, performed the experiments, and analyzed and interpreted the data. All authors read and approved the final manuscript.

\section{Funding}

The study was supported by Reckitt Benckiser Healthcare Ltd, UK. Employees of the funder were responsible for the design of the study, collection, analysis, and interpretation of data, and writing the manuscript. 


\section{Availability of data and materials}

The datasets used and/or analyzed during the current study are available from the corresponding author on reasonable request.

\section{Ethics approval and consent to participate}

Not applicable.

\section{Consent for publication}

Not applicable.

\section{Competing interests}

DM, OA and AS are employees of Reckitt Benckiser Healthcare Ltd, UK.

\section{Author details}

${ }_{1}^{1}$ Reckitt Benckiser Healthcare International Ltd, 103-105 Bath Road, Slough, Berkshire SL1 3UH, UK. ${ }^{2}$ Reckitt Benckiser Healthcare UK Ltd, Dansom Lane, Hull HU8 7DS, UK.

Received: 8 January 2020 Accepted: 13 February 2020

Published online: 24 February 2020

\section{References}

1. Pelucchi C, Grigoryan L, Galeone C, Esposito S, Huovinen P, Little P, et al. Guideline for the management of acute sore throat. Clin Microbiol Infect. 2012;18(Suppl 1):1-28.

2. Ebell MH, Smith MA, Barry HC, Ives K, Carey M. The rational clinical examination. Does this patient have strep throat? JAMA. 2000;284:2912-8.

3. Worrall GJ. Acute sore throat. Can Fam Physician. 2007;53:1961-2.

4. Shephard A, Smith G, Aspley S, Schachtel BP. Randomised, doubleblind, placebo-controlled studies on flurbiprofen $8.75 \mathrm{mg}$ lozenges in patients with/without group A or C streptococcal throat infection, with an assessment of clinicians' prediction of 'strep throat'. Int J Clin Pract. 2015:69:59-71.

5. Radkova E, Burova N, Bychkova V, DeVito R. Efficacy of flurbiprofen $8.75 \mathrm{mg}$ delivered as a spray or lozenge in patients with sore throat due to upper respiratory tract infection: a randomized, non-inferiority trial in the Russian Federation. J Pain Res. 2017:10:1591-600.

6. Dagnelie CF, Touw-Otten FW, Kuyvenhoven MM, Rozenberg-Arska M, de Melker RA. Bacterial flora in patients presenting with sore throat in Dutch general practice. Fam Pract. 1993;10:371-7.

7. Gergova RT, Petrova G, Gergov S, Minchev P, Mitov I, Strateva T. Microbiological features of upper respiratory tract infections in bulgarian children for the period 1998-2014. Balkan Med J. 2016;33:675-80.

8. Mihancea N. Frequency and distribution per species, biotypes, resistance to antibiotics and beta-lactamase production of the haemophils isolated from patients with respiratory diseases. Roum Arch Microbiol Immunol. 1998;57:125-37.

9. Batty A, Wren MW. Prevalence of Fusobacterium necrophorum and other upper respiratory tract pathogens isolated from throat swabs. $\mathrm{Br} J$ Biomed Sci. 2005;62:66-70.
10. van Driel ML, De Sutter A, Deveugele M, Peersman W, Butler CC, De Meyere $M$, et al. Are sore throat patients who hope for antibiotics actually asking for pain relief? Ann Fam Med. 2006;4:494-9.

11. WHO (World Health Organization). Antibiotic resistance key facts. February 2018. https://www.who.int/en/news-room/fact-sheets/detail/antib iotic-resistance. Accessed 5 Feb 2020.

12. Addey D, Shephard A. Incidence, causes, severity and treatment of throat discomfort: a four-region online questionnaire survey. BMC Ear Nose Throat Disord. 2012:12:9.

13. McNally D, Shephard A, Field E. Randomised, double-blind, placebo-controlled study of a single dose of an amylmetacresol/2,4-dichlorobenzyl alcohol plus lidocaine lozenge or a hexylresorcinol lozenge for the treatment of acute sore throat due to upper respiratory tract infection. J Pharm Pharm Sci. 2012;15:281-94.

14. McNally D and Scheiner M. Acute sore throat, Module 1551. April 2011. http://www.chemistanddruggist.co.uk/maincontent/-/article_displ ay_list/4406146/updatemodule-1551-acute-sore-throat. Accessed 5 Feb 2020.

15. Buchholz V, Leuwer M, Ahrens J, Foadi N, Krampfl K, Haeseler G. Topical antiseptics for the treatment of sore throat block voltage-gated neuronal sodium channels in a local anaesthetic-like manner. Naunyn Schmiedebergs Arch Pharmacol. 2009;380:161-8.

16. Shephard A, Zybeshari S. Virucidal action of sore throat lozenges against respiratory viruses parainfluenza type 3 and cytomegalovirus. Antiviral Res. 2015;123:158-62

17. Morokutti-Kurz M, Graf C, Prieschl-Grassauer E. Amylmetacresol/2,4dichlorobenzyl alcohol, hexylresorcinol, or carrageenan lozenges as active treatments for sore throat. Int J Gen Med. 2017;10:53-60.

18. Chaudhuri RK. Hexylresorcinol: Providing skin benefits by modulating multiple molecular targets. In: Sivamani R, Jagdeo JR, Elsner P, Maibach $\mathrm{HI}$, editors. Cosmeceuticals and Active Cosmetics. Boca Raton: CRC Press; 2015. p. 71-81.

19. Kemme M, Heinzel-Wieland R. Quantitative assessment of antimicrobial activity of PLGA films loaded with 4-hexylresorcinol. J Funct Biomater. 2018;9:E4.

20. NIH (US National Library of Medicine). PubChem. Hexylresorcinol. https:// pubchem.ncbi.nlm.nih.gov/compound/Hexylresorcinol. Accessed 5 Feb 2020.

21. Matthews D, Atkinson R, Shephard A. Spectrum of bactericidal action of amylmetacresol/2,4-dichlorobenzyl alcohol lozenges against oropharyngeal organisms implicated in pharyngitis. Int J Gen Med. 2018;11:451-6.

22. Wade AG, Morris C, Shephard A, Crawford GM, Goulder MA. A multicentre, randomised, double-blind, single-dose study assessing the efficacy of AMC/DCBA Warm lozenge or AMC/DCBA Cool lozenge in the relief of acute sore throat. BMC Fam Pract. 2011;12:6.

\section{Publisher's Note}

Springer Nature remains neutral with regard to jurisdictional claims in published maps and institutional affiliations.

Ready to submit your research? Choose BMC and benefit from

- fast, convenient online submission

- thorough peer review by experienced researchers in your field

- rapid publication on acceptance

- support for research data, including large and complex data types

- gold Open Access which fosters wider collaboration and increased citations

- maximum visibility for your research: over $100 \mathrm{M}$ website views per year

At BMC, research is always in progress.

Learn more biomedcentral.com/submissions 